\title{
Gender related differences in the use of the Internet by university academics
}

\author{
Maria Tsvere ${ }^{1}$, Srikanta Swamy ${ }^{2}$, Leonorah Tendayi Nyaruwata ${ }^{3}$ \\ ${ }^{I}$ (Department of Curriculum and Instruction, Chinhoyi University of Technology, Zimbabwe) \\ ${ }^{2}$ (Center for Research, Christ University, India) \\ $\left({ }^{3}\right.$ Higher Degrees Programme, Zimbabwe Open University, Zimbabwe)
}

\begin{abstract}
This paper reports in part some of the findings of a PhD study regarding visibility of gender issues in the use of the internet in university contexts. The study adopted a cross sectional descriptive survey research design and collected data using a structured questionnaire. Data were obtained from 440 full time university academics that were selected using simple random sampling technique. Data were analysed quantitatively using descriptive and inferential statistics using SPSS version 17. This study revealed a significant relationship between gender and internet usage in favour of males. While both male and female academics were not fully utilizing the internet for university teaching, more male academics used the internet for research more than female academics did. The study concluded that gender is a key factor in the discourse concerning internet and university academic practice. Internet usage differences have serious implications on mainstreaming ICT in higher education curricula as both female and male academics are expected to mentor students and participate in virtual co-construction of knowledge. The study recommended that university management should develop gender sensitive information technology learning environments and targeted training programmes. Female lecturers should be encouraged to be proactive and participate in global developmental initiatives.
\end{abstract}

Keywords: Gender, academics, Internet usage, Search engines, university teaching.

\section{Introduction}

Developments in information and communication technology are revolutionizing university education system across the globe (Kumar and Manjunath, 2013 [1]; Tsvere, Nyaruwata and Swamy, 2013 [2]). Schmidt and Cohen (2013) [3] inform that the internet is transforming the knowledge economy. Technology innovation particularly the internet is also at the heart of transformations that are taking place in humanity (Gurumurthy, 2004) [4]. This innovation has technological and social implications. The internet and Web 2.0 have brought in new technologies that, if well utilized can transform the learning and university pedagogy (Downes, 2010 [5]; Schmidt and Cohen, 2013 [3]). This study was conducted at a time when Africa was lagging behind in terms of Internet penetration and when Zimbabwe was having an internet quality of about 15\% (De Argaez, 2013 [6]). Zimbabwe was also in a process of mainstreaming ICT in the education sector. Literature reveals that gender is the defining factor in development issues (Wieslaw, Adyta and Kaja, 2012 [7]; Hafkin and Huyer, 2007 [8]; Gurumurthy, 2004 [4]; UNESCO, 2003 [9]). Wamala (2012) [10] noted that technology developers were not taking into account gender issues. The debate surrounding gender and technology focused mainly on issues of access and seeing women as objects of information. Gurumurthy (2004) [4] informs that women and women organisations advocated for equitable access to means of public expression, professional careers, decisionmaking positions and how women were being portrayed by different media during the 1990's.

This study was motivated by the ongoing discourse surrounding use of the ICT by women in developing countries (Wieslaw et al., 2012) [7]. This study therefore engages in the latest debated surrounding use of latest technologies in the education sector considering that the internet was not created for teaching/learning purposes. The paper reports part of an ongoing $\mathrm{PhD}$ study regarding visibility of gender issues in university teaching and research with respect to the uses of the internet as a teaching and research tool. The main purpose of the study was to provide insight into the relationship between gender and internet usage in university education contexts. Hilbert (2011) [11] identified the need for clarifying whether being a woman per se has negative, neutral or positive effect on ICT usage.

Specifically the study sought to:

\section{Research Objectives}

- Establish internet access points for male and female university academics.

- Investigate how male and female academics use the internet for university educational purposes.

- Find out whether there were gender differences in the use of the internet as an academic tool.

The following hypothesis was tested;

$\mathrm{H}_{0}$ : There is no significant difference between mean scores of internet usage with respect to gender 


\section{Literature Review}

This study was informed by the gendered approach. This approach sustains that technology is neither inherently neutral nor inherently masculine. Gender and technology are cultural processes that can be negotiated and transformed (Gajjala, 2002) [12]. This theoretical framework assumes that gender is the nub of debates surrounding utilization of information and communication technologies. Gajjala (2002) [12] adds that local histories, geographical conditions and everyday cultural practices determine how technology is used. Use of ICT is also influenced by such factors as access (Warschauer, 2004 [13]; Kirkman, 1999 [14]) and ICT competency of users (Tsvere et al., 2013 [2]). The internet was created for military defence as a research tool (Sebesta, 2012 [15]; Gopalan and Akilandeswari, 2011 [16]). University academics require relevant educational information and resources for research, lesson planning and delivery. Academics also need relevant information and knowledge as well as opportunities to communicate either with their students or with other academics.

The internet provides a wide range of information resources through databases and search engines. Anyira (2013) [17] explains that internet users prefer such search engines as WebCrawler because it browses the net using a logical robotic comportment that provided up-to-date information. Anyira (2013) also identifies Google (http://www.google,com/), MSN Search (http://www.msn.com/) and Lycos (http://www.lycos.com/ as popular search engines. The Directory of Open Access Journals (DOAJ) (www.doaj.org), African Journals Online (AJOL) (www.ajol.info), Health Inter Network Access to Research Initiative (HINARI) and J-STOR African Access Initiative (www.jstor.org), Ebookee (www.ebookee.org) also provide valuable up-to-date online journals and e-books.

Information seeking behaviour was found to be gender related (Wilson, 1999 [18]; Hotchkiss, 2008 [18]). Anyira (2013) [17] in South-South Nigeria found a significant gender difference between male and female lecturers' level of awareness of search engines and use of Google search engine. Luan, Aziz, Yunus et al., (2005) [20] found significant gender differences related to use of search engines and file uploads. Hilbert (2011) [11] noted a three to fifteen percent gender difference in internet use in favour of men in Australia, Hungary, New Zealand and a two to three percent difference in favour of women in Sweden and United States. Research reveals that boys use the internet for different purposes more than girls (Anyira, 2013 [17]; Madhusudhan, 2007 [21]) although the reasons for use converge at adolescent stage. They revealed that a majority of women use internet for their studies, to download films, music and for shopping (Mlambo, 2005) [22] and social (Dalberg Global, 2012) [23] or health related information (Cline and Haynes, 2001) [24]. Men use the internet for news and gaming (Dalberg, 2012) [23]. Literature has also shown that men tend to use the internet more than women (Anyira, 2013) [17]. Women were found to use the internet for social e-mailing more than males by Hotchkiss (2008) [19]. Parameshwar and Patil (2009) [25] supports Anyira (2013) [17] and Hotchkiss (2008) [19] that gender is considered as an important factor in the use of information technology.

The gender divide is explained by socio-cultural preconceptions about interactions of women with technologies and attitude towards domestic responsibilities. Gurumurthy (2004) [4] notes that in poor and less developed countries, women and girls were less able to access information technology than men and boys. UNDP (1999) [26], reports that parents in the United States spent twice as much on ICTs for their sons than they did for their daughters. Mlambo (2005) [22] established that women did not use internet because they were uncomfortable with the technology (technophobia) or were not interested in using it. Gurumurthy (2004) [4] noted that the majority of women in the world, who did not use the internet, were excluded from the World Wide Web. Internet providers tend to be discouraged from providing adequate connectivity when areas have isolated users. This happens often in rural communities where population density is poor. That disadvantages women who comprise the majority in rural areas. Hilbert (2011) [11] supporting Mlambo (2005) [22], reports that technophobia has been identified as an influencing factor in developing countries. The internet is therefore introducing new dynamics of information use, information sharing and access to user friendly software. The question of how university male and female academics are making use of the internet in university academic business therefore becomes critical for any government.

\section{Data Collection Method}

This study targeted male and female full time university academics in Zimbabwe. The study adopted a cross sectional descriptive survey research design. This study used valid responses obtained from 440 university academics. The sample was selected using the simple random sampling technique. Data were collected through a structured questionnaire. This question format was adopted so that the same frame of reference applied to the male and female participants. The internet usage scale had Cronbach's alpha reliability coefficient of 0.83 . The questionnaire was administered in person to the sample with permission from the heads of the various universities. Data were then summarised and analysed using percentages, mean scores and tabulations. Relationships among variables were explored using non parametric statistics. The correlations were explored and the hypothesis was tested using the SPSS version 17 for Windows. 


\section{Findings And Discussion}

5.1 Access and intensity of internet usage

Respondents had up to five years university teaching experience. The majority of the male respondents (55.3\%) and $46.6 \%$ of the female respondents had used the internet for at least six years. More than eighty percent of both male and female respondents had access to computers and the internet in university offices. The proportion of male respondents $(68.6 \%)$ who had access to the internet from ICT laboratory was higher than that of female respondents (64.7\%). More male respondents (59.1\%) could access internet from cyber cafes than female respondents $(55.7 \%)$. Again more male respondents $(46.6 \%)$ could access the internet at home than female respondents $(42.0 \%)$. The proportion of males $(67.8 \%)$ who had access to internet on mobile phones was almost the same as that of female respondents (67.6\%). At the time of study, only seven male respondents had tablets of which six which were connected. Mahmood and Bokhari (2012) [27] established similar differences among university students. Hilbert (2011) [11] blames gender insensitive working conditions, education opportunities and inadequate income as factors which contribute to having fewer women accessing and using ICT. Fig. 1 shows the intensity of internet use by university academics studied.

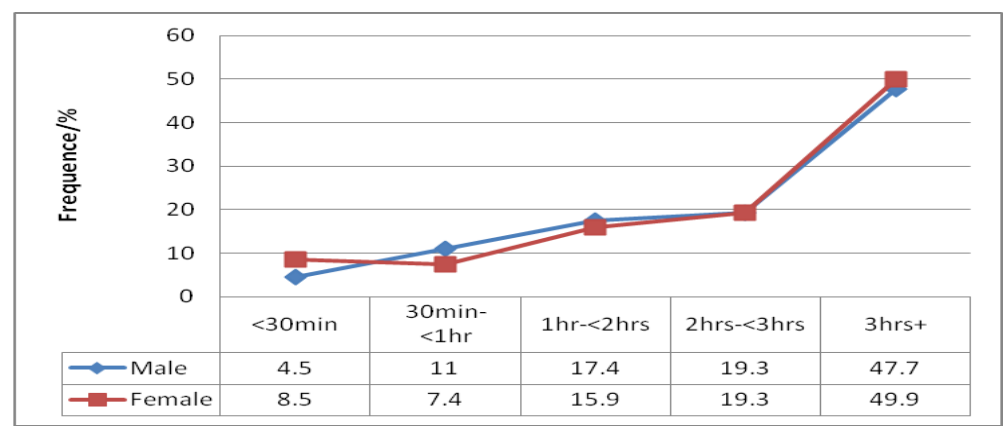

Figure 1: Time spent per day on the internet by gender

The majority of respondents spent more than three hours per day using the internet (Fig.1). An analysis of time spent by respondents on the net in university office revealed a slightly higher proportion of the male respondents spending two or more hours per day on the net $(71.5 \%)$ than the proportion of female respondents who spent that time in university offices $(70.3 \%)$. Although male respondents spent more time on the internet than their female counterparts, the difference was found to be not significant. Hilbert (2011) [11] observed that intensity of internet use does not depend on gender but depends on the country. Women carry the triple burden of household, productive and reproductive roles which significantly occupy their time (Tsvere, 2012) [28]. Time needed for performing gender roles reduce time per day let for them to adopt and use new technologies such as the internet.

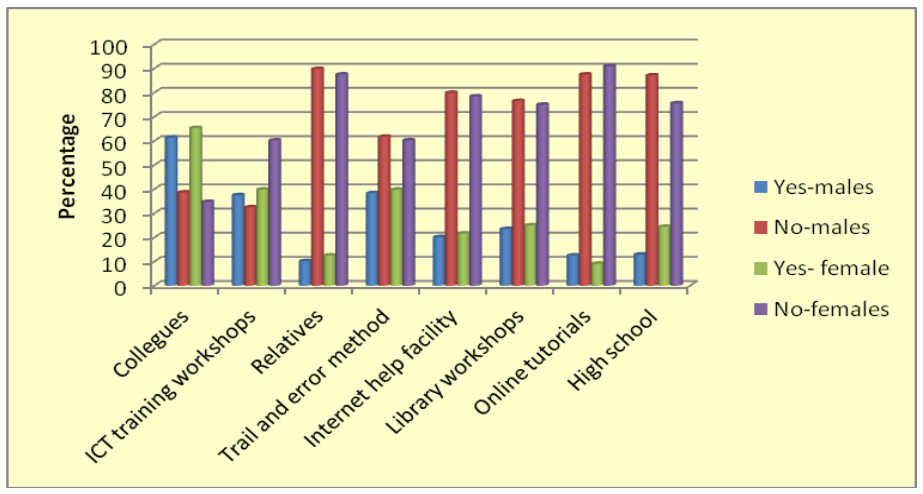

Figure2: Respondents' sources of knowledge of how to use the internet

The majority of the respondents ( $36.8 \%$ male and $26.1 \%$ female) were taught how to use the internet by colleagues while $23.0 \%$ male and $15.9 \%$ females used the trial and error method. These findings were in concordance with Kumar and Manjunath (2013) [1] who found that Kuvempu University, Karnataka state academics used self instruction and trial and error method. Online tutorials and help facility on the net were least exploited by both male and female respondents (Fig. 2). This study revealed that only a small percentage had been exposed to ICT prior to joining universities and only $17.5 \%$ respondents had had exposure to ICT during high school. 


\subsection{Information seeking behaviour of female and male academics}

The majority of the respondents $(88.2 \%)$, irrespective of gender, did not maintain a personal web page. This study also revealed that $66.7 \%$ of male and $75.6 \%$ of female respondents had challenges in creating and editing a web page. This study also revealed that $30.7 \%$ of female and $42.8 \%$ of the male respondents had published an article in an online journal. Tsvere et al., (2013) [2] established that competency in using the internet for research was significantly related to gender in favour of males. Tsvere et al., (2013) [2] also found out that $35.6 \%$ of male respondents and $46.0 \%$ of the female respondents had challenges in uploading documents for publishing in online journals. Writing for knowledge production requires that academics critically review related literature. The teaching and learning environment involves resource search and information collection and utilization. With the fast growing knowledge industry, physical libraries are being replaced by internet and Web technology. Table 1 summarises the extent to which male and female respondents use the selected popular search engines

Table 1: Summary of Search engines used by respondents expressed as a percentage

\begin{tabular}{|c|c|c|c|c|c|c|c|c|c|c|c|c|c|c|c|}
\hline & \multicolumn{3}{|c|}{ Always } & \multicolumn{3}{|c|}{ Often } & \multicolumn{3}{|c|}{ Sometimes } & \multicolumn{3}{|c|}{ Seldom } & \multicolumn{3}{|c|}{ Not yet used } \\
\hline & $\frac{3}{0}$ & 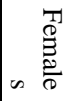 & $\stackrel{\overrightarrow{0}}{\stackrel{0}{D}}$ & $\underset{\infty}{\frac{3}{\infty}}$ & 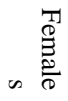 & $\stackrel{-1}{\grave{D}}$ & $\frac{3}{2}$ & 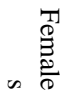 & $\stackrel{-1}{\stackrel{0}{D}}$ & $\frac{3}{20}$ & 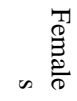 & $\begin{array}{l}\text { - } \\
\stackrel{0}{D}\end{array}$ & $\frac{3}{2}$ & 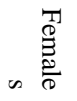 & $\stackrel{-1}{\stackrel{0}{D}}$ \\
\hline Google & 71.2 & 71.6 & 71.4 & 18.9 & 18.8 & 18.9 & 4.2 & 5.1 & 4.5 & 1.9 & 0.6 & 1.4 & 3.8 & 4.0 & 3.9 \\
\hline MSN & 5.7 & 7.4 & 6.4 & 5.3 & 5.7 & 5.5 & 8.7 & 9.1 & 8.9 & 13.3 & 10.2 & 12.0 & 67.0 & 67.6 & 67.3 \\
\hline Yahoo & 22.3 & 26.1 & 23.9 & 15.5 & 16.5 & 15.9 & $\begin{array}{l}12 . \\
5\end{array}$ & 15.3 & 13.6 & 12.1 & 8.0 & 10.5 & 37.5 & 34.1 & 36.1 \\
\hline Ask & 4.9 & 2.8 & 4.1 & 5.3 & 10.2 & 7.3 & 5.7 & 9.1 & 7.0 & 5.3 & 6.8 & 5.9 & 78.8 & 71.0 & 75.7 \\
\hline $\begin{array}{l}\text { Google. } \\
\text { Scholar }\end{array}$ & 24.2 & 25.0 & 24.5 & 16.3 & 18.8 & 17.3 & 9.8 & 11.4 & 10.5 & 6.8 & 5.7 & 6.4 & 42.8 & 39.2 & 41.4 \\
\hline $\begin{array}{l}\text { Web- } \\
\text { Crawler }\end{array}$ & 2.3 & 1.7 & 2.0 & 2.7 & 2.3 & 2.5 & 1.9 & 3.4 & 2.5 & 3.8 & 2.3 & 3.2 & 89.4 & 90.3 & 89.8 \\
\hline
\end{tabular}

Google was found to be the most popular search engine by both male (71.2\%) and female $(71.6 \%)$ of the male and female respondents. Use of Yahoo, MSN and Google or Meta search engines was not significantly associated with gender. Meta search engines were least popular for both male and female respondents (Table 1). The majority of respondents irrespective of their gender had not yet used Meta search engines. This study revealed that $94.3 \%$ and $96.0 \%$ of the male and female respondents had not yet used Ithaki; $95.8 \%$ of male and $96.0 \%$ of female respondents had not yet used Ixquick; $95.1 \%$ of male and $95.5 \%$ of the female respondents had not yet used Surfwax and $94.7 \%$ of male and $97.7 \%$ of female respondents had not yet used Vivismo. Such search engines allow for deep search. WebCrawler for example enable researchers and educators to quickly find free, relevant full text reader friendly educational resources from renowned academics. The results are supported by Anyira, 2013) [17]. Nwosu and Anyira (2011) [29] also found a significant gender difference between male and female use of Google which was found to be in favour of men. Nwosu and Anyira (2011) [29] contrary to this study's findings found no gender difference in the use of Yahoo search engine.

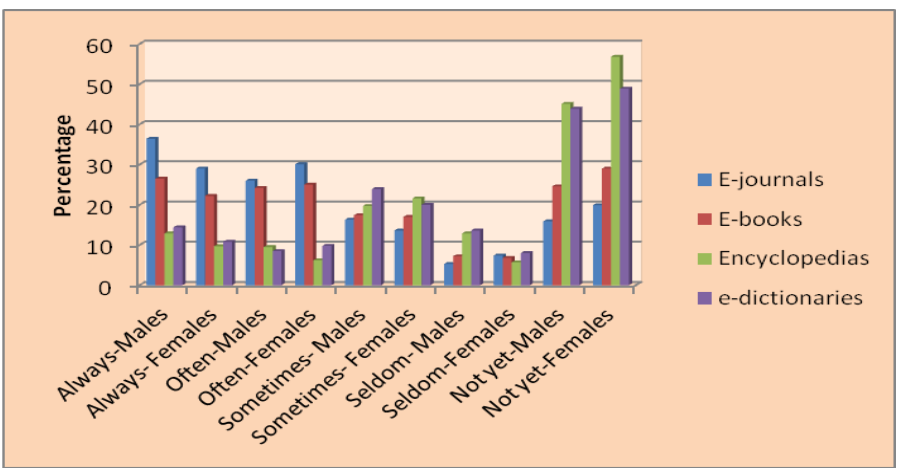

Figure 3: Summary of e-resources used by respondents

Use of the above electronic resources was not significantly associated with gender. Respondents used internet to access e-journals and e-books more than they did e-encyclopaedias and e-dictionaries. The proportion of male respondents $(26.5 \%)$ that always used e-books was higher than that of female respondents $(22.2 \%)$. The difference was not statistically significant. The use of encyclopaedias was significantly related to gender Cramer's $V=0.157, \mathrm{p}<0.028$ although the overall percentage of male and female respondents who used 
encyclopaedias was less than $15 \%$. The proportion of male respondents $(62.5 \%)$ who use e-journals was more than that of female respondents $(29.1 \%)$ but again the difference was not statistically significant. Table 2 summarises what respondents used internet for.

Table 2: Summary of uses expressed as a percentage

\begin{tabular}{|c|c|c|c|c|c|c|c|c|c|c|c|c|c|c|c|}
\hline & \multicolumn{3}{|c|}{ Always } & \multicolumn{3}{|c|}{ Often } & \multicolumn{3}{|c|}{ Sometimes } & \multicolumn{3}{|c|}{ Seldom } & \multicolumn{3}{|c|}{ Not yet used } \\
\hline Used to- & $\frac{3}{\frac{3}{0}}$ & $\begin{array}{l}\frac{T}{9} \\
\stackrel{0}{0} \\
\stackrel{2}{8}\end{array}$ & 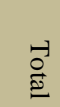 & $\frac{3}{8}$ & 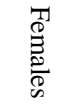 & $\stackrel{0}{\ddot{D}}$ & $\frac{3}{8}$ & 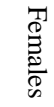 & $\stackrel{-1}{\stackrel{0}{\ddot{D}}}$ & $\begin{array}{l}3 \\
\frac{3}{8} \\
8\end{array}$ & 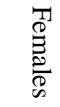 & $\stackrel{\vec{O}}{\grave{D}}$ & $\frac{3}{8}$ & $\begin{array}{l}\frac{T}{1} \\
\stackrel{0}{2} \\
\frac{2}{8}\end{array}$ & 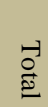 \\
\hline $\begin{array}{l}\text { Prepare } \\
\text { teaching } \\
\text { material } \\
\end{array}$ & $\begin{array}{l}42 . \\
8\end{array}$ & $\begin{array}{l}36 . \\
9\end{array}$ & $\begin{array}{l}40 . \\
5\end{array}$ & $\begin{array}{l}33 . \\
3\end{array}$ & $\begin{array}{l}33 . \\
5\end{array}$ & $\begin{array}{l}33 . \\
4\end{array}$ & $\begin{array}{l}18 . \\
2\end{array}$ & $\begin{array}{l}22 . \\
7\end{array}$ & $\begin{array}{l}20 . \\
0\end{array}$ & 3.0 & 4.0 & 3.4 & 2.7 & 2.8 & 2.7 \\
\hline $\begin{array}{l}\text { Deliver } \\
\text { lectures }\end{array}$ & 4.2 & 4.5 & 4.3 & $\begin{array}{l}10 . \\
2\end{array}$ & 8.0 & 9.3 & $\begin{array}{l}12 . \\
1\end{array}$ & $\begin{array}{l}12 . \\
5\end{array}$ & $\begin{array}{l}12 . \\
3\end{array}$ & $\begin{array}{l}17 . \\
4\end{array}$ & $\begin{array}{l}11 . \\
9\end{array}$ & $\begin{array}{l}15 . \\
2\end{array}$ & 56.2 & $\begin{array}{l}63 . \\
1\end{array}$ & $\begin{array}{l}58 . \\
9\end{array}$ \\
\hline $\begin{array}{l}\text { Design } \\
\text { online tests }\end{array}$ & 2.7 & 5.7 & 3.9 & 9.8 & 9.7 & 9.8 & $\begin{array}{l}17 . \\
0 \\
\end{array}$ & $\begin{array}{l}17 . \\
0 \\
\end{array}$ & $\begin{array}{l}17 . \\
0 \\
\end{array}$ & $\begin{array}{l}15 . \\
5 \\
\end{array}$ & $\begin{array}{l}12 . \\
5 \\
\end{array}$ & $\begin{array}{l}14 . \\
3 \\
\end{array}$ & 54.9 & $\begin{array}{l}55 . \\
1 \\
\end{array}$ & $\begin{array}{l}55 . \\
0 \\
\end{array}$ \\
\hline $\begin{array}{l}\text { *Provide } \\
\text { feedback to } \\
\text { students }\end{array}$ & 9.5 & 8.0 & 8.9 & $\begin{array}{l}22 . \\
3\end{array}$ & $\begin{array}{l}11 . \\
9\end{array}$ & $\begin{array}{l}18 . \\
2\end{array}$ & $\begin{array}{l}26 . \\
5\end{array}$ & $\begin{array}{l}35 . \\
2\end{array}$ & $\begin{array}{l}30 . \\
0\end{array}$ & $\begin{array}{l}14 . \\
4\end{array}$ & $\begin{array}{l}13 . \\
1\end{array}$ & $\begin{array}{l}13 . \\
9\end{array}$ & 27.3 & $\begin{array}{l}31 . \\
8\end{array}$ & $\begin{array}{l}29 . \\
1\end{array}$ \\
\hline $\begin{array}{l}\text { Testing } \\
\text { online }\end{array}$ & 2.7 & 2.8 & 2.7 & $\begin{array}{l}11 . \\
0\end{array}$ & 8.5 & $\begin{array}{l}10 . \\
0 \\
\end{array}$ & $\begin{array}{l}16 . \\
7 \\
\end{array}$ & 8.5 & $\begin{array}{l}13 . \\
4 \\
\end{array}$ & $\begin{array}{l}20 . \\
8 \\
\end{array}$ & $\begin{array}{l}26 . \\
7 \\
\end{array}$ & $\begin{array}{l}23 . \\
2 \\
\end{array}$ & 48.9 & $\begin{array}{l}53 . \\
4 \\
\end{array}$ & $\begin{array}{l}50 . \\
7 \\
\end{array}$ \\
\hline $\begin{array}{l}\text { Share } \\
\text { knowledge }\end{array}$ & 4.2 & 6.2 & 5.0 & $\begin{array}{l}16 . \\
3 \\
\end{array}$ & $\begin{array}{l}13 . \\
1 \\
\end{array}$ & $\begin{array}{l}15 . \\
0 \\
\end{array}$ & $\begin{array}{l}18 . \\
2 \\
\end{array}$ & $\begin{array}{l}11 . \\
9\end{array}$ & $\begin{array}{l}15 . \\
7 \\
\end{array}$ & $\begin{array}{l}25 . \\
0 \\
\end{array}$ & $\begin{array}{l}23 . \\
9\end{array}$ & $\begin{array}{l}24 . \\
5 \\
\end{array}$ & 36.4 & $\begin{array}{l}44 . \\
9 \\
\end{array}$ & $\begin{array}{l}39 . \\
8 \\
\end{array}$ \\
\hline $\begin{array}{l}\text { *Further } \\
\text { personal } \\
\text { developmen } \\
\mathrm{t}\end{array}$ & $\begin{array}{l}27 . \\
3\end{array}$ & $\begin{array}{l}25 . \\
6\end{array}$ & $\begin{array}{l}26 . \\
6\end{array}$ & $\begin{array}{l}34 . \\
1\end{array}$ & $\begin{array}{l}20 . \\
1\end{array}$ & $\begin{array}{l}28 . \\
6\end{array}$ & $\begin{array}{l}19 . \\
3\end{array}$ & $\begin{array}{l}28 . \\
4\end{array}$ & $\begin{array}{l}23 . \\
0\end{array}$ & 6.8 & 8.5 & 7.5 & 12.5 & $\begin{array}{l}17 . \\
0\end{array}$ & $\begin{array}{l}14 . \\
3\end{array}$ \\
\hline $\begin{array}{l}\text { *Publish } \\
\text { research } \\
\text { output }\end{array}$ & $\begin{array}{l}23 . \\
3\end{array}$ & $\begin{array}{l}10 . \\
2\end{array}$ & $\begin{array}{l}17 . \\
5\end{array}$ & $\begin{array}{l}14 . \\
0\end{array}$ & $\begin{array}{l}15 . \\
3\end{array}$ & $\begin{array}{l}14 . \\
5\end{array}$ & $\begin{array}{l}21 . \\
6\end{array}$ & $\begin{array}{l}21 . \\
6\end{array}$ & $\begin{array}{l}21 . \\
6\end{array}$ & $\begin{array}{l}14 . \\
0\end{array}$ & $\begin{array}{l}18 . \\
8\end{array}$ & $\begin{array}{l}15 . \\
9\end{array}$ & 28.0 & $\begin{array}{l}34 . \\
1\end{array}$ & $\begin{array}{l}30 . \\
5\end{array}$ \\
\hline
\end{tabular}

*internet usage was significantly associated with gender

This study established that giving feedback and or homework to students online was found to be significantly associated with gender $(\mathrm{V}=0.152, \mathrm{p}=0.038)$. The number of males who communicated with students online was significantly higher than that of females. Similarly, use of internet for personal development was found to be significantly related to gender $(\mathrm{V}=0,170, \mathrm{p}=0.013)$. The proportion of male respondents who use the internet for furthering their professional development was significantly higher that that of females. Mlambo (2005) [22] also found that women use the internet for their studies. This study revealed a significant strong relationship between using internet for publishing research output and gender $(\mathrm{V}=0.163$, $\mathrm{p}=0.019$ ). The same observation was found by Mahajan (2006) [30]. Dalberg Global (2012) [23] revealed that use of the internet for education related activities and emailing were not related to gender. Hilbert (2011) [11] supported Gajjala (2002) [12] who noted that use of technology was contextual; depending on access to the technology and such factors as the country, local histories and geographical conditions.

Almost all male $(94.3 \%)$ and female $(93.1 \%)$ respondents used the internet for e-mailing. This study found that a majority of male and female respondents had not used document delivery systems $(73.9 \%$ of male and $81.2 \%$ of female respondents respectively). A higher proportion of males $(24.9 \%)$ than females $(12.5 \%)$ used newsgroups for educational functions. None of the academics used electronic translation services. This same observation was revealed in terms use of university staff/student e-learning portals. The majority, that is, $54.9 \%$ of the male and $58.0 \%$ of the female respondents did not use staff/student e-learning portals. Again only $22.0 \%$ of the male and $17.6 \%$ of the female respondents used discussion groups. This study also revealed that $62.5 \%$ of male and $57.4 \%$ of female respondents had Face book accounts but only $25.8 \%$ o the males and $19.9 \%$ of the females with face book accounts always used Face book as a teaching/learning tool. Again only $21.6 \%$ of male and $17.0 \%$ of the female respondents had Twitter accounts. This study revealed that only eight percent of the male and nine percent of the female respondents used social media to communicate with other academics.

Table 3: Independent samples t-test for mean differences between mean scores of internet usage for male and female respondents

\begin{tabular}{|l|l|l|l|l|l|l|l|}
\hline Variables & $\begin{array}{l}\text { No } \\
\text { subjects }\end{array}$ & Mean & SD & df & t & $\begin{array}{l}\text { Sig.(2- } \\
\text { tailed) }\end{array}$ & Decision \\
\hline Males & 264 & 2.90 & .74 & 438 & 2.337 & 0.020 & $\begin{array}{l}\text { Reject null hypothesis; } \\
\text { difference is significant }\end{array}$ \\
\hline
\end{tabular}


This study found a highly significant strong association between use of newsgroups and gender $(\mathrm{V}=$ $0.161, \mathrm{p}=0.001)$. Table 3 compares the mean scores of internet usage of male and female respondents assuming a null hypothesis of no significant difference in the means. The mean score of internet usage of male respondents ( $M=2.90, S D$ 0.74) was higher than that of female respondents ( $M=2.70, S D 0.77)$. The t-test result revealed a significant difference between the mean scores of internet usage of the male and that of the female respondents $(t=2.337, p=0.020, \alpha=0.05)$. The stated null hypothesis was rejected. The result revealed that use of internet was significantly related to gender in favour of males. A Post hoc Dunnett t-test analysis result showed that the gender difference existed in using the internet as a research tool, and no such difference existed in use of the internet as a teaching tool. The major explanation for this difference was explained by the finding that both male and female academics had challenges in using the internet for teaching but they had fair knowledge and skill in using the same for research (Tsvere et al, 2013) [2]. Internet usage was also found to be related to competency and that ICT competency was significantly related to gender in favour of males (Tsvere et al., 2013) [31]. These findings corroborate with Gurumurthy (2004) [4] who found that women relate to technology differently and their use of technology in institutions is influenced by institutional power dynamics and gender relations.

\subsection{Implications}

The knowledge economy and world of work is being transformed by the fast diffusing information technology, the internet in particular. A strategic investment in university education becomes an inevitable strategy for speeding up development of human capital and economic growth. Developing countries like Zimbabwe, are striving to improve teaching and learning practices by adopting a gender responsive pedagogy and mainstreaming ICT in education curricular. This implies a need for developing teachers' leadership in applications of ICT. That is only possible if both male and female academics benefit equally from information technologies and their applications. This implies that gender analyses should be part of the discourse surrounding applications of ICT particularly the internet. University academics, as academic leaders, should ensure that information technology is properly utilised as an enabler for university learning and knowledge production. This study has revealed that both male and female academics spent more than two hours per day on the net. They both need to research and prepare lectures. Universities need to improve on delivery practices by using information technology in the teaching and learning process. Hafkin and Huyer (2007) [8]support these findings arguing that ICT literacy and skills are central to including and encouraging women to participate in and benefit from and contribute to the information society.

Search engines are making it possible for academics to access current freely available literature found in different forms on the net. The internet has more than 100 search engines which cover a variety of search and educational needs. This study focused mainly on search engines that were likely to be used by Zimbabwean academics such as Google, MSN Search, Yahoo, Surfwax, IxQuick, and Ithaki. Google supersedes the library catalogues or other online citation databases (Griffiths and Brophy, 2005 [32]; Reiger, 2010) [33]. A sound understanding of search contexts, e-resources and their uses is an essential part if university education practices. That awareness helps management and librarians to develop staff development programmes that enhance search capabilities of internet users.

Inequalities in the use of Information Technology may negatively affect educational development opportunities as well as economic and social fronts. Malhotra, Kanesathasan and Patel (2012) [34] had observed that women in technology lack role models, mentors, support networks. Gurumurthy (2004) [4] also informs that gender and women's right to access and use ICTs is central to decisions about who benefits from ICTs and those who dictate the course of ICTs. In developing countries access and utilization of ICTs is heavily influenced by strategic control processes that include sexism, power dynamics and monopolies surrounding intellectual property rights and increasing surveillance of the internet.

Apart from being a human right and equity issue, closing the gender gap is one of arbiters of efficiency and productivity. ICTs are effective tools for social transformation and gender equality (Gurumurthy, 2004) [4] in e-commerce, e-governance, health and information sharing. Mlambo (2005) [22] found that women participating at word processing and data entry levels in the world of work instead of striving for leadership positions. Contributing to the knowledge economy is vital for university academics as that helps to improve visibility of academic leadership. Female academics need to participate in online debates and share their profiles including expertise and research output online as well otherwise they will remain invisible to those who need them as role models. This study advises that the choice made by the Zimbabwean government to invest in ICT infrastructure for its educational institutions to enhance education and training become more successful if the whole process is gendered.

\section{Conclusions And Recommendations}

This study has highlighted that internet is impacting on educational practices including university teaching and research. This study revealed that the mean score of internet usage of male academics was significantly different from that of female respondents. The study also established that using internet for professional development, publishing research output and giving feedback was significantly related to gender in 
favour of males. The study also concluded that there is a strong positive relationship between use of newsgroups and gender in favour of males. This study also concluded that internet as a technology is having a gender differential impact on the way university academics use the internet for academic business. The study recommends that university management should go beyond increasing access and use of ICTs by women to engendering the whole ICT system; which is a prerequisite for restructuring of the knowledge society. Such transformation should include developing ICT policies that consider gender when developing staff developing programmes so that both male and female academics benefit equally from the internet and staff development programmes.

In order to increase the visibility of women and academic leadership through ICT the study recommends that university management should introduce and promote those social structures that promote positive social relations and social capital. Gender sensitization and gender mainstreaming workshops should be held so that university management that is male dominated in Zimbabwe becomes aware of gender issues surrounding ICT usage in institutions of higher education. University management should earmark funds for ICT courses for targeted training, enhanced career development counselling for women to remove technophobia and stereotypes that act as barriers to the advancement of women in this ever changing techno-environments. Female academics should also be encouraged to use the internet in teaching and to increase their visibility in the academic field by publishing in online journals, university institutional repositories and improve or update their profiles on university websites. More research needs to be done on how other demographic variables, university leadership style and social environments influence use of the internet in university teaching and learning.

\section{References}

[1] B.T.S. Kumar, and G. Manjunath, Internet use and its impact on the academic performance of university teachers and researchers: A comparative study, Higher Education, Skills and Work-based Learning, 3(3), 2013, 219-238.

[2] M. Tsvere, S. Swamy, and L.T. Nyaruwata, Perceived competencies of university academics in the use of information and communication technology in university academic business, International Journal of Science and Research, 2(8), $2013,284-289$.

[3] E. Schmidt, and J. Cohen, The new digital age: reshaping the future of people, nations and business (London: John Murray, 2013).

[4] A. Gurumurthy, Gender and ICTs: an overview report (Institute of Development Studies: Bridge, 2004).

[5] S. Downes, The role of educator in a PLE world, Stephen's Web, 2010, http://www.downes.ca/post/54321.

[6] E. De Argaez, Africa Internet users, 2013, http://www.internetworldstat.com/stats.htm

[7] O. Wieslaw, J. Adyta, and Z-K, Kaja, Gender issues in information and communication technologies (ICTs), Journal of Information, Communication and Ethics in Society, 10(2), 2012), 107-120.

[8] N. Hafkin, and S. Huyer, Women and gender in ICT statistics and indicators for development, Information Technologies and International Development, 4(2), 2007, 25-41.

[9] UNESCO, Gender issues in the information society, 2003, http://portal.unesco/org/ci/en/file download.php/

[10] C. Wamala, Empowering women through ICT (Stockholm: Stockholm University ICT4D Series 4, 2012.)

[11] M. Hilbert, Digital genders divide or technologically empowered women in developing countries? A typical case of lies, damned lies, and statistics, Women's Studies International Forum, 34(6), 2011), 479-489.

[12] R. Gajjala, Cyberferminist technological practices: exploring possibilities for a women-centered design of technological environments, 2002, http://www.un-instra.org/doc/gender_and_ict/gajjala.pdf.

[13] M. Warschauer, Technology and social inclusion: rethinking the digital divide (Cambridge Massachusetts: the MIT Press, 2004).

[14] G. Kirkman, It's more than just being connected. A discussion of some of the issues of Information Technology and international development, Development Commerce Workshop discussion paper, Cambridge: Massachusetts Institute of Technology, 1999, 1-13.

[15] R.W. Sebesta, Programming the World Wide Web, $4^{\text {th }}$ ed., (Delhi: Pearson, 2012).

[16] N.P. Gopalan, and J. Akilandeswari, Web technology: a developer's perspective (New Delhi: PHI learning Ltd., 2011).

[17] I. E. Anyira, Gender implications in awareness and use by private university lecturers in South-South Nigeria, Library Philosophy and Practice, 2013, http://www.digitalcommon.un1/libphilprac/109.

[18] T. Wilson, Information behaviour: an interdisciplinary perspective, Information Processing and Management, 33(4), 1999, 551-572.

[19] W. S. Luan, S.A. Aziz, S.M. Yunus, Z. Sidek, K.A. Bakar, M. Meseran, and H. Atan, Gender differences in ICT competencies among academics of University Putra, Malaysia, Malaysian Journal of Information Technology, 2(3), 2005, 62-69.

[20] G. Hotchkiss, Human hardware: men and women,2008, http://searchengineland.com/human-hardware

[21] M. Madhsudhan, Internet use by research scholars in University of Delhi, India, Library Tech News, 8, 2007, 36-42.

[22] E. Mlambo, gender dimension of the use of ICT in universities: the case of University of Zimbabwe, 2005, http://ir.uz.ac.zw/jspu/bitstream/10646/53/THE GENDER DIMENSION OF THE USE OF ict-FINALS05.pdf

[23] Dalberg Global, Women and the Web: bridging the internet gap and creating new global opportunities in the low and middle income countries (United States: Intel, 2012).

[24] R.J.W. Cline and K. M. Haynes, Consumer health internet seeking on the internet: the state of the Art, Health Education Research, 16(6), 2001, 761-692.

[25] S. Parameshwar, and D. Patil, Use of the Internet by faculty and research scholars of Gulbarga University, Library Philosophy and Practice, 2009, http://unillib.unl.edu/LPP/parameshwar-patil.htm

[26] UNDP, Human development report, 1999: globalization with a human face,1999, http://hdr.undp.org/reports/global/1999/en

[27] A. Mahmood, and N. H. Bokhari, Use of Information and Communication Technology: gender differences among students at tertiary level, Journal of Education and Instructional Studies in the World, 2(6), 2012, 100-108.

[28] M. Tsvere, Mainstreaming gender in energy projects in rural communities of Zimbabwe: a case study of Jengeta huni stove in Magunje, Mashonaland West province, Journal of Zimbabwe, Arts, Humanities and Education, 1(1), 2012, 61-74.

[29] O. Nwosu, and I. Anyira, Inquiry into the use of Google and yahoo search engines in retrieving web resources by internet users in Nigeria, Indian Journal of Information Sources and Services, 1(2), 2011, 61-67.

[30] P. Mahajan, Internet use by researchers: a study of Punjab University, Chandigarh, Library Philosophy and Practice, 2006, http://unillib.unl.edu/LPP/mahajan2.htm. 
[31] M. Tsvere, S. Swamy, and L.T. Nyaruwata, Internet usage by university academics: Implications for the $21^{\text {st }}$ Century, International Journal of Science and Research, 2(9), 19-25.

[32] J. R. Griffiths, and P. Brophy, students' searching behaviour and the Web: use of academic resources and Google, Library Trends, 53(4), 2005, 539-554.

[33] O.Y. Reiger, Search engine use behaviour of students and faculty: user perceptions and implications for future research, First Monday, 14(12-70, 2009, http://firstmonday.org/ojs/index.php/fm/article/view/2716/2385.

[34] A. Malhotra, A. Kanesathasan, and P. Patel, Connectivity: how mobile phones, computers and the internet can catalyse women's entrepreneurship in India: A case study (India, International Center for Research on Women, 2012). 